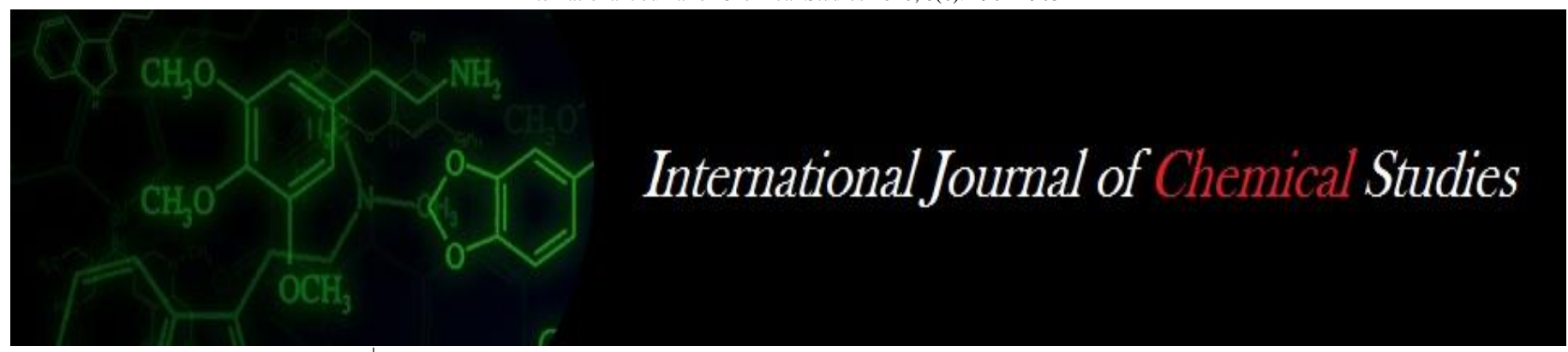

P-ISSN: 2349-8528

E-ISSN: 2321-4902

www.chemijournal.com

IJCS 2020; 8(6): 1902-1905

(C) 2020 IJCS

Received: 14-09-2020

Accepted: 21-10-2020

Godavarthi Srilekha

M.Sc. Research Scholar,

Department of Agronomy,

School of Agriculture, Lovely

Professional, University,

Jalandhar, Punjab, India

Corresponding Author: Godavarthi Srilekha

M.Sc. Research Scholar,

Department of Agronomy,

School of Agriculture, Lovely

Professional, University,

Jalandhar, Punjab, India

\section{A review on impact of herbicides on weeds in wheat}

\section{Godavarthi Srilekha}

DOI: https://doi.org/10.22271/chemi.2020.v8.i6aa.11045

\begin{abstract}
Weed infestation would be major restriction in the production of wheat because weeds competes with plants for moisture, nutrients, light. As the wheat crop observed in various agroclimatic conditions different irrigation regimes, cropping sequences, it is infested with diverse type of weed flora. Depending on the type of weeds, their density and environmental factors, yield losses will vary. Weeds are most harmful to the crops. Weeds interfere with the crops during different crop growth stages. There by it reduces the growth and yield of the crop drastically. Therefore, different weed management practices have been taken to reduce the crop weed competition, especially by using herbicidal treatments. For mitigating weeds in the wheat crop, growers mainly depends on herbicides, as they are cost effective. The herbicides should be selected appropriately on the basis of selectivity, so they do not harm the main crop. All the pre and post emergence herbicides were proven to be efficient in reducing weed density, dry accumulation of weeds and significantly maximum N, P, K uptake, protein content and yield over rest of the weed control treatments.
\end{abstract}

Keywords: Depending, herbicides, wheat, production, maximum

\section{Introduction}

Wheat is the second most extensively grown cereal crop in the world. Wheat is the most important food grain and ranks 2 nd in the overall production as a cereal crop behind maize and the third being rice. It is the staple food for over 10 billion people in as many as 43 countries of the world. It provides nourishment to $35 \%$ of world population. Cultivation of wheat has traditionally been dominated by the northern region of India. The major wheat production states are Uttar Pradesh, Punjab, Haryana, Madhya Pradesh, Rajasthan, Bihar, Himachal Pradesh. The northern states of Punjab and Haryana plains in India have been abundant wheat producers. It is a staple food for the North India where people prefer for chapatti. As one of the top most produced crops, it is grown for its highly nutritious purpose. Nutritional composition of wheat grain varies with climate and soil. On an average, kernel contains $12 \%$ water, $70 \%$ carbohydrates, $12 \%$ protein, fat, vitamins, minerals, crude fiber each of $2 \%$, Thiamine, niacin, riboflavin and small amounts of vitamin A are present. Mostly wheat used for food requires processing. The greatest portion of wheat flour produced is used for bread making. Wheat grown in dry climates are generally hard types, having protein content of $11-15 \%$ and strong gluten. The hard type wheat (Triticum aestivum) produces flour which is best suited for bread making. The wheat of humid areas are softer, with protein content of about $8-10 \%$ and weak gluten. The softer type club wheat (Triticum compactum) produces flour suitable for making cakes, cookies, pastries. Durum wheat (Triticum durum) is used for making pastas such as spaghetti and macroni. Wheat straw used to feed livestock. Additionally, wheat is used by industry for the production of starch, pasta, malt, gluten and other products. There are many factors that affect the crop production such as late sowing, improper seed rate, method of sowing, inadequate plant population, lack of irrigation water at critical stages of crop, disease, insects and weeds. Most important factor among them is weed attack. Competition of weeds is one of the major factors in reducing the yield of any crop (Siddiqui \& Bajwa, 2010) ${ }^{[31]}$. (Chaudhry et al.; 2008; Dalley et al.; 2006) ${ }^{[8,13]}$ reported that decline in yield is maximum due to high intensity and competition of the weeds. There are many reports on inhibitory impacts of weeds on the crop (Bhowmik and Doll, 1992; Javid et al.; 2007) ${ }^{[6,20]}$. 
Anything that reduces the space, reduces the plant growth (Wright et al.; 2001) ${ }^{\text {[34] }}$. There is a possibility of spreading diseases as weeds reduces the volume and quality of the produce, it directly effect on yield. (Marwat et al.; 2008) ${ }^{[26-}$

${ }^{27]}$. Reduction in the yield due to weeds by competing for the nutrients, fluorescence, moisture and place. (Shehzad et al.; $2013)^{[29]}$. Globally, around $80 \%$ of cereal production from the major food crops like wheat, rice, maize, but the unwanted plants directly effect the yield of the crop. Wheat crop usually affected with the broadleaf and grassy weeds, it reduces the yield of 7-50\% which depends on the nature of weed flora and their intensity (Singh et al.; 2004) ${ }^{[32]}$. Weed infestation during the early stages of crop is one of the major factors responsible for lower wheat productivity. Weeds consume 3-4 times more $\mathrm{N}, \mathrm{P}, \mathrm{Mg}$ than weed free crop. Weed infestation is a serious problem affecting the crop growth and yield all over the world. Weeds could attack any ecosystem, therefore researchers focused to evaluate how the diversity of weeds has affected the yield of the crop. (Davis et al., 2009) ${ }^{[14]}$. Utilization of resources by the weeds is more than crop plants because weeds are hard and can withstand extreme climatic conditions. Weeds competition with the crop for light, water, nutrients, spaces and for several furthur growth components, which directly affects the product quality and quantity through the competitiveness and allelopathy. (Gupta, 2004) ${ }^{[17]}$. Weeds not only lowers the quality of the produce but also increases the cost of harvesting, threshing and cleaning. Weeds lower the market value of the produce and hence bring huge economic losses to the growers. Weeds may encourage the development of diseases, provides shelter and acts as an alternate host for pests (Marwat et al.; 2005) ${ }^{[28]}$. By increased weed density, it results in the reduction of grain yield. Similar findings were recorded by Katara et al.; $2012^{\text {[22] }}$ and Chaudhari et al.; $2016^{[7]}$. Presence of weeds in a crop can adversely affect production in a no. of ways. Weeds reduces quality, increasing harvesting costs of the produce, increases the fire risks. (Arnon 1972) ${ }^{[4]}$. To trigger excess grain yield of wheat, it is crucial to management of weeds, it results in higher yield. (Khan et al.; 2003) ${ }^{[23]}$. Weed management increases the cost of production and thus it is necessary to use such methods which reduce not only the cost of production but also save time and labour. Accurate control of weeds is a key factor to sustain crop yield. If proper weed control methods are operated during the critical period, then effective management will be done. Depending on the purpose of the crop produce, nature of weeds, resource availability. Various weed control methods are used to control the weeds. Apart from the improved agronomic practices and preventive measures, chemical weed control is one of the important key factors to enhance the wheat production and productivity. Chemical weed control method is effective method because it decreases the losses of crop production because of weed infestation and decreases further weed infestation. Herbicides are a quick tool to control dense weed populations. However, with the increasing labour, power costs chemical application is the only best way for effective weed management. Herbicides are cheap, reliable and effective method of weed control, which provides consistently higher net return to the farmers. (Ahmed et al. 1993) ${ }^{[2]}$ Noticed that chemical application, manual weeding reduced weeds dry weight in a significant manner. For controlling weeds, herbicide control is proved to be most effective and economical method. (Marwat et al.; 2008) [26-27]. Chemical weed control method is preferable over the other weed control as it is much effective as well as low cost and the total herbicides reduced weed number and significantly improved yield, also yield factors of the wheat crop as compared to control (Chaudhry et al.; 2008) ${ }^{[8]}$. High grain yield was attained over the herbicides treated plots at the first weed development stage (Barros et al.; 2009) ${ }^{[5]}$. Dosage, selectivity of herbicide, proper time of application directly impacts on the herbicide effectiveness. (Steckel et al.; 1997) ${ }^{[33]}$. Chemical method of control enables farmers to obtain higher yields per unit area with an overall lower production cost. Use of herbicides as lower application could result the problem of low or no weed control. Similarly, higher application often involves the heavy expenditures and causes environmental hazard in addition to adverse affects on wheat crop. Adding overdose of chemical herbicides which develops resistance in various weed species associated with wheat crop. Usage of the same herbicide continuously for years, it may generate resistance to the weed plants against the herbicide efficiency. So, we must stop the use of those herbicides before the resistance developed which is only possible when we know about the herbicide efficiency. Hence, the present study was designed to determine the efficacy of different pre and post emergence herbicides compared to the hand weeding in controlling weeds in wheat.

\section{Competition of weeds}

Due to poor agronomic methods, weeds dominate over the crop. So, it is necessary to know the competition between crop and weeds. Weeds compete with the main crop for nutrients, light, moisture, space. So, competition of weeds is the major problem in production. Competition occurs when crop and weeds grows in the closer proximities. After rice harvesting in rice-wheat cropping, if there is sufficient soil moisture weeds grow before the wheat crop, or else they grow with the main crop. Reduction in wheat yield primarily due to decline in tiller number. Avena fatua, P. minor comes under grass family having habit of growth, development like wheat, because of this it is difficult to differentiate these weeds from wheat in vegetative stage. Critical weed control period in wheat is 30 to 45 days DAS and during this period, crop should be kept weed free.

\section{Weed flora and shift of weed flora}

Weed flora of the crop varies from place to place, it depends on the type of soil, irrigation, weed control measures for weeds, cropping sequences and environmental conditions. (Anderson, Beck 2007, Chhokar, Malik 2002, Chhokar et al., 2007 a\&b., Dixit et al., 2008 a\&b) ${ }^{[3,10,11,15]}$. Broadleaf weeds and grassy weeds infest the wheat but severe loss occur due to grassy weeds than the broadleaf weeds. Rumex dentatus L., Medicago denticulate from the broad leaved category and P. minor from grassy weeds most commonly found in the irrigated wheat.

\section{Measures to control weeds}

There are 3 different weed management methods namely chemical, physical or mechanical, cultural and preventive weed control.

\section{Cultural and preventive measures}

Preventive measures like using of manures, clean seeds, cultural methods like sowing time and method, crop geometry and density of crop, crop rotation, crop variety, dosage, type of irrigation have definite impact on the crop weed interference. 


\section{Use uncontaminated wheat seeds free from weed}

Weed seed contaminated with the crop seeds is one of the major factor responsible for the spreading of weeds. Farmers have to use cleaned seed or cleaned seed or certified seed. Contaminated seeds reduces the crop seed rate thereby reduction in yield.

\section{Time of sowing}

Sowing date may be modified in such a manner that it is not favourable for germination of weed seeds without obstructing yield of crop. Late sown wheat mostly affected with the Phalaris minor than the early sown. However it is crucial not to modify wheat seeding a lot from optimum sowing time, else yields would be reduced.

\section{Row spacing, Seed rate}

Increased competitive capacity of wheat crop with the weeds could be accomplished by raising the plant population with raising seeding rate or decreasing space for the weed by close spacing, cross sowing. Because of good canopy coverage, high density and closer spacing smother the weeds.

\section{Mechanical method}

It includes removing the weeds with the help of many tools, implements by including manual weeding, uprooting. Even the manual weeding is effective, it includes significant time and man-power. This methods feasibility is much less because of scarce labour and high cost. Mechanical weeding is also difficult, where weeds similar morphologically to the crop eg. Phalaris minor and Avena ludoviciana before flowering in the wheat crop.

\section{Weed control by using chemicals}

Usage of herbicide is preferred due to much efficiency as well as less involvement of time and cost. Good weed control practice rely on suitable herbicide selection depending on weed flora type infesting plant in addition herbicide must be applied with optimum dose through suitable application method. Application of herbicides significantly reduces the density and biomass of the broad and narrow leaf weeds to a varying degree sometimes approaching to $100 \%$ control (Hashim et al. (2002) ${ }^{[18]}$ and Khan et al. (2003) ${ }^{[23]}$. Control of weeds provides enough space for crop growth and leaf expansion and therefore LAI also increases. Shoeran et al. (2013) ${ }^{[30]}$ reported positive effect of herbicides on yield of wheat crop. Weed control measures decreases the competition of crop plants with weeds and led to effecient utilization of available resources, thereby increasing the yield. Chaudhry et

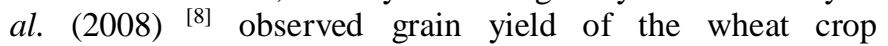
significantly raised by usage of the various chemicals for the weed control as compared to weedy check. Weed control in wheat crop concluded that herbicides suppressed weed population effectively. Herbicides significantly reduce weed density. Due to minimal weed competition by using of herbicides, it causes an increased flow of nutrients towards the grain and ultimately yield was increased. Hence effective weed control is needed for harvesting possible maximum grain yield with good quality. Abbas et al., 2009 [1], Malik et al.; $2009^{[25]}$ \& Marwat et al.; $2008^{[26-27]}$ observed that by using of herbicides, grain yield in wheat was increased.

\section{Herbicides impact on yield, yield related characters of wheat}

Yield attributes like, height of plant, no. of productive spikes, grains for each spike, grain yield affected by weed controlling treatments. Among the yield parameters of the crop, number of grains per spike is essential parameter to evaluate the effect of weed management on produce. Increase in no. of grains for each spike would improve weight of spike, it definitely increases the final yield (Hussain et al.; 2013) ${ }^{[19]}$. Good yield, yield components owing to high weed control in weed density reduction and weed biomass. Higher value of LAI was achieved by controlling the grassy and broad leaved weeds as it provides enough space for crop growth and leaf expansion. No. of grains per spike decreased due to weeds. In herbicide treated area longer spike might be due to good weed control as well as allocation of much resources to the plant than weeds. (Cheema and Akhtar 2005) ${ }^{[9]}$. And the maximum weed control improved the production of fertile tillers which subsequently contributed towards increase in wheat yield. All weed control measures tended to improve $\mathrm{N}, \mathrm{P}, \mathrm{K}$ content. Nutrient uptake by crop is mainly a function of yield and nutrient content. As highest nutrient uptake in the herbicidal treatment which might be due to decreased crop weed competition by increasing the nutrient availability, improved crop growth and higher crop biomass production. A weedy crop resulted in least nutrient uptake because the applied nutrients shared by the weeds because of their competitiveness and the better root system. By application of weed control measures tended to enhance N,P,K uptake. Supressing of the weed flora leading to the less competition for nutrients resulted in higher uptake of nutrients by wheat. It indicates that controlling weeds resulted in increase in grain yield and significantly effect on straw yield of wheat. Weed control by all means increased the protein content by wheat grain.

\section{Conclusion}

Wheat is major cereal crop in India. So management of weeds in wheat is important. When compared with other weed management practices, chemical weed control practice has much significance in suppressing the weeds and increasing the grain yields. Chemical weed control practice is fore chosen since there is less involvement of the labor as well as no mechanical damages for crop which happens at manual weeding. Furthermore, chemical control method is more efficacious since weeds within the row are also killed, otherwise which consistently elude, due to morphological resemblance to the wheat at the time of mechanical control. Therefore, encouragement of researchers has importance for exploring mode of the action and resistance phenomenon of herbicides against the toxic weeds.

\section{References}

1. Abbas G, Ali MA, Abbas Z, Aslam M, Akram M. Impact of different herbicides on broadleaf weeds and yield of wheat. Pak. J Weed Sci. Res 2009;15(1):1-10.

2. Ahmad K, Shah Z, Khan I, Khan M, Khan MQ. Effect of post-emergence herbicides application and hand weeding on wheat and weed pressure. Pak. J Weed Sci. Res 1993, 6(1-2).

3. Anderson RL, Beck DL. Characterizing weed communities among various rotations in central South Dakota. Weed Technology 2007;21(1):76-79.

4. Arnon I. Crop production in dry regions. Volume 2. Systematic treatment of the principal crops 1972.

5. Barros J, Basch G, Freixial R, Carvalho M. Effect of reduced doses of mesosulfuron+ iodosulfuron to control weeds in no-till wheat under Mediterranean conditions 2009. 
6. Bhowmik PC, Doll JD. Corn and Soybean Response to Allelopathic Effects of Weed and Crop Residues 1. Agronomy Journal 1982;74(4):601-606.

7. Chaudhary D, Singh PK, Chopra NK, Rana SC. Effect of herbicide and herbicide mixture on weeds in wheat. Indian Journal Agricultural Research 2016;50(2):107122.

8. Chaudhry S, Hussain M, Ali MA, Iqbal J. Efficacy and economics of mixing of narrow and broad leaved herbicides for weed control in wheat. Journal of Agricultural Research (Pakistan) 2008.

9. Cheema MS, Akhtar M. Efficacy of different post emergence herbicides and their application methods in controlling weeds in wheat. Pakistan Journal of Weed Science Research 2005;11(1/2):23-29.

10. Chhokar RS, Malik RK. Isoproturon-resistant littleseed canarygrass (Phalaris minor) and its response to alternate herbicides1. Weed Technology 2002;16(1):116-123.

11. Chhokar RS, Sharma RK, Jat GR, Pundir AK, Gathala MK. Effect of tillage and herbicides on weeds and productivity of wheat under rice-wheat growing system. Crop protection 2007;26(11):1689-1696.

12. Chhokar RS, Sharma RK, Pundir AK, Singh RK. Evaluation of herbicides for control of Rumex dentatus, Convolvulus arvensis and Malva parviflora. Indian Journal of Weed Science 2007;39(3and4):214-218.

13. Dalley CD, Bernards ML, Kells JJ. Effect of weed removal timing and row spacing on soil moisture in corn (Zea mays) 1. Weed Technology 2006;20(2):399-409.

14. Davis AS, Hall JC, Jasieniuk M, Locke MA, Luschei EC, Mortensen DA et al. Weed science research and funding: a call to action. Weed Science 2009;57(4):442-448.

15. Dixit A, Gogoi AK, Varshney JG. Weed Atlas-Districtwise distribution pattern of major weed flora in prominent crops. Vol I, National Research Centre for Weed Science, Jabalpur, India 2008, 127.

16. Dixit A, Gogoi AK, Varshney JG. Weed Atlas-Districtwise distribution pattern of major weed flora in prominent crops. Vol I, National Research Centre for Weed Science, Jabalpur, India 2008, 88.

17. Gupta OP. Modern weed management. Agrobios Jodhpur, India. IAE Mohamed, Comparative efficiency of certain 2004;2:18-23.

18. Hashim SAIMA, Marwat KB, Hassan G. Response of wheat varieties to substituted urea herbicides. Pakistan Journal of Weed Science Research (Pakistan) 2002.

19. Hussain Z, Marwat KB, Munsif F, Samad A, Ali K. Evaluation of various herbicides and their combinations for weed control in wheat crop. Pak. J Bot 2013;45(1):5559.

20. Javaid A, Bajwa R, Rabbani N, Anjum T. Comparative tolerance of rice (Oryza sativa L.) genotypes to purple nutsedge (Cyperus rotundus L.) allelopathy. Allelopathy Journal 2007;20(1):157.

21. Javald A. Effect of six problematic weeds on growth and yield of wheat. Pakistan Journal of Botany 2010;42(4):2461-2471.

22. Katara P, Kumar S, Rana SS, Chander N. Combination of pinoxaden with other herbicides against complex weed flora in wheat. Indian Journal of weed science 2012;44(4):225-230.

23. Khan MH, Hassan G, Khan N, Khan MA. Efficacy of different herbicides for controlling broadleaf weeds in wheat. Asian Journal of Plant Sciences 2003.
24. Kumar S, Agrawal KK, Kewat ML, Kumhar BL. Effect of post emergence herbicides on yield and economics of wheat 2019.

25. Malik AU, Hussain I, Ahmad M, Haji MA, Ali M. Demonstration and evaluation of effect of weedicides on broad leaved weeds on wheat yield. JAPS, Journal of Animal and Plant Sciences 2009;19(4):193-196.

26. Marwat KB, Saeed M, Hussain Z, Gul B, Rashid H. Study of various herbicides for weed control in wheat under irrigated conditions. Pakistan Journal of weed science Research 2008;14(1/2):1-8.

27. Marwat KB, Saeed M, Hussain Z, Gul B, Rashid H. Study of various herbicides for weed control in wheat under irrigated conditions. Pakistan Journal of weed science Research 2008;14(1/2):1-9.

28. Marwat KB, Hussain Z, Saeed M, Gul B, Noor S. Chemical weed management in wheat at higher altitudes. Pak. J Weed Sci. Res 2005;11(3-4):102-107.

29. Shehzad M, Tanveer A, Ayub M, Mubeen K, Ibrahim M, Qadir I, Sarwar N. Effect of weed-crop competition on growth and yield of Garden Cress. Sarhad J Agric 2013;29(1):79-82.

30. Shoeran S, Punia SS, Yadav A, Singh S. Bioefficacy of pinoxaden in combination with other herbicides against complex weed flora in wheat. Indian Journal of Weed Science 2013;45(2):90-92.

31. Siddiqui I, Bajwa R. Effect of six problematic weeds on growth and yield of wheat. Pak J Bot 2010;42:24612471.

32. Singh G, Singh VP, Singh M. Bio-efficacy of metribuzin and prometryn in wheat. Indian Journal of Weed Science 2004;36(3and4):178-180.

33. Steckel GJ, Wax LM, Simmons FW, Phillips WH. Glufosinate efficacy on annual weeds is influenced by rate and growth stage. Weed Technology 1997, 484-488.

34. Wright A, Egan S, Westrup J, Grodecki A. Weed management for successful plant establishment. Produced by Community Education and Extension support. NRM facts, vegetation series 2001, 48 . 